\title{
Nucleic acid metabolism in the ruminant
}

\author{
Determination of nucleic acids in digesta
}

\author{
By A. B. McALLAN AND R. H. SMITH \\ National Institute for Research in Dairying, Shinfield, Reading.
}

(Received I3 Fanuary 1969-Accepted I7 April 1969)

\begin{abstract}
1. Procedures, based on those of Schmidt \& Thannhauser (1945) and Schneider (1945), for the extraction and estimation of nucleic acids in bovine digesta were examined in detail.

2. Final methods which were suitable for routine determination of RNA and DNA were essentially as follows. Digesta samples were extracted in the cold, first with a solution of trichloroacetic acid in ethanol, then with aqueous trichloroacetic acid solution and finally with lipid solvents. The dried residue was hydrolysed with alkali, purified by passage through a Dowex resin, and the RNA, in the form of mononucleotides, determined by u.v. absorption. DNA was determined separately in hot perchloric acid extracts of the original dried residue by colorimetric estimation of the deoxyribose content.
\end{abstract}

Nucleic acids form a quantitatively important part of the nitrogen presented to the ruminant duodenum (Smith, McAllan \& Hill, 1968) but they have rarely been determined in digesta. An extensive literature exists for the extraction of nucleic acids from animal tissues. The most generally satisfactory methods appear to be those based on the procedures of Schmidt \& Thannhauser (r945) and Schneider (r945). The methods, and subsequent modifications to them, have been reviewed and critically assessed by Hutchison \& Munro (196r, 1962) and Munro \& Fleck (1966, 1967). Methods based on these procedures have also been used for plant tissues (de Deken-Grenson \& de Deken, 1959) and bacteria (Volkin \& Astrachan, 1956) although difficulties have been encountered, particularly from the presence of interfering material. Digesta from the rumen and upper small intestine of ruminants present special problems since both plant material, degraded to a greater or lesser extent, and considerable numbers of micro-organisms are present. For this reason McDonald (I954) attempted to assess the nucleic acid content in sheep digesta by measuring purine bases after hydrolysis. Topps \& Elliott (1965) attempted the determination of total nucleic acids in the rumen contents of sheep by simple extraction and estimation techniques and Ellis \& Pfander (1965) used an undescribed modification of the Schmidt-Thannhauser method. From our experience it seems likely that considerable errors from interfering materials could have been involved in these determinations. The only fully described method giving a separate measure of ribonucleic acid (RNA) and deoxyribonucleic acid (DNA) is that of Gausseres \& Fauconneau (1965). RNA was determined by the fractional separation of the mononucleotides and DNA by the fractional separation of the purine bases. These procedures suffer from the disadvantage of being very time consuming and are unsuitable for routine use.

We have investigated in detail the conditions of extraction, purification and determination of the individual nucleic acids by the Schmidt-Thannhauser and Schneider 
methods and have developed procedures suitable for applying these basic methods to digesta samples.

\section{METHODS AND RESULTS}

The procedure eventually adopted for the determination, which has been briefly described previously (McAllan \& Smith, I968), is outlined in Fig. r. The steps in the procedure will be considered individually. Subsequent reference in the text to step numbers correspond to those indicated in Fig. I.

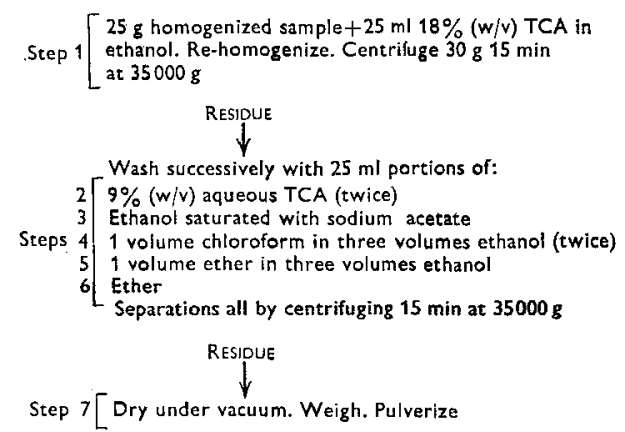

RNA

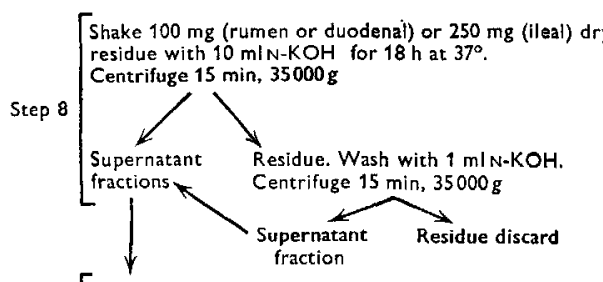

DNA

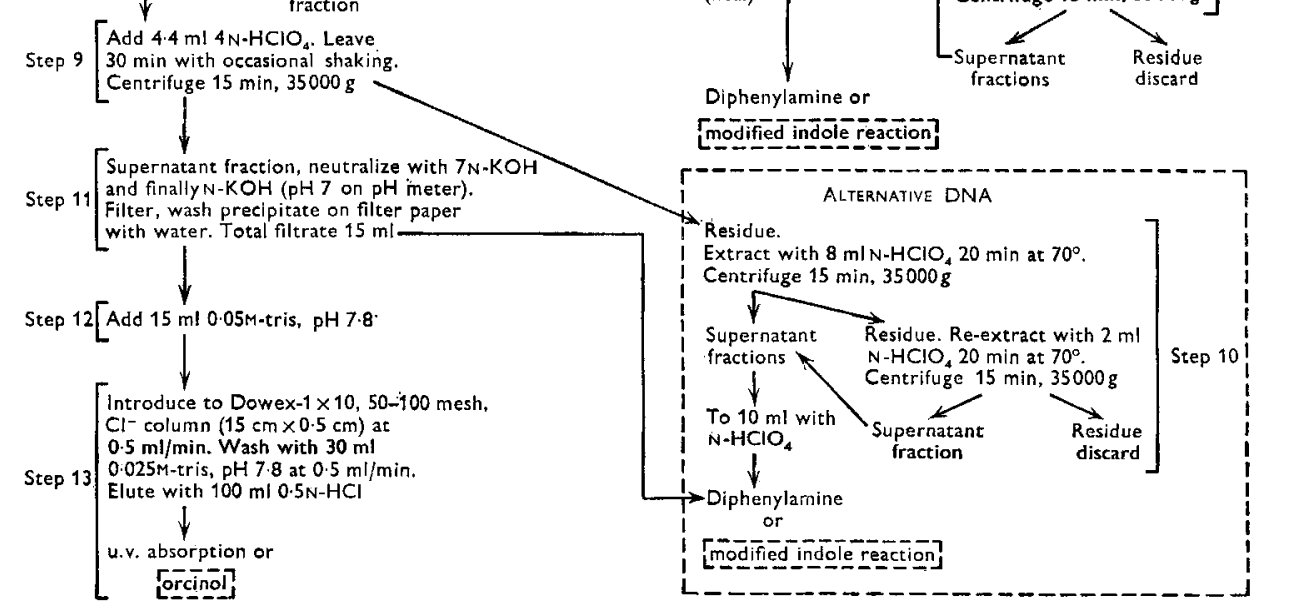

Fig. I. Schematic outline of the standard procedure finally adopted for the extraction and estimation of RNA and DNA in digesta samples. The manipulations enclosed within broken lines are alternative procedures which were used during the development of the method but were not used in the normal routine standard procedure. During steps $1-6$ (inclusive), 9 and 11 , all reagents were at $0-4^{\circ}$ and all operations were carried out at $0-4^{\circ}$. 


\section{Collection and preliminary treatment of sample}

Samples were obtained from cows or calves which were fistulated in the rumen, duodenum or ileum and collected directly into vessels surrounded by ice. Further treatment was started within $2 \mathrm{~h}$ of collection. Rumen samples were usually filtered through coarse muslin to remove large food particles, but apart from this the different types of digesta were treated in the same way. All were homogenized before being subjected to the extraction procedure.

Initial extraction. Attempts were made in early experiments to homogenize samples directly with aqueous trichloroacetic acid (TCA) but the homogenates were very difficult to separate by centrifuging. A preliminary extraction with ethanol caused

Table I. Effect of varying the alkali concentration, the digestion time, or both, on the extraction of $R N A$ from ether-dried residues from digesta samples. $R N A$ was determined by u.v. absorption at $260 \mathrm{~nm}$ and results are expressed as $\mathrm{mg} R N A / \mathrm{IOO} \mathrm{g}$ water in the digesta

\begin{tabular}{|c|c|c|c|}
\hline \multirow[b]{2}{*}{ Digesta sample } & \multicolumn{2}{|c|}{ N-KOH } & \multirow{2}{*}{$\begin{array}{c}0.3 \mathrm{~N}-\mathrm{KOH} \\
\text { I h, } 37^{\circ}\end{array}$} \\
\hline & $20 \mathrm{~h}, 37^{\circ}$ & I $h, 37^{\circ}$ & \\
\hline $\begin{array}{r}\text { Rumen: } \\
\mathbf{B}\end{array}$ & $\begin{array}{l}42 \cdot 5 \\
45 \cdot 6\end{array}$ & - & $\begin{array}{l}31 \cdot 0 \\
22 \cdot 5\end{array}$ \\
\hline $\begin{array}{r}\text { Duodenal: } \\
\text { B }\end{array}$ & $\begin{array}{l}43 \cdot 9 \\
45 \cdot 8\end{array}$ & - & $\begin{array}{l}43 \cdot 9 \\
42 \cdot 6\end{array}$ \\
\hline Ileal & $23 \cdot 9$ & 17.8 & $17 \cdot 5$ \\
\hline
\end{tabular}

some improvement but good separations were obtained most consistently by first homogenizing the sample with a solution of TCA in ethanol (step I). In view of the findings of Hallinan, Fleck \& Munro ( 1963 ) of losses of RNA on treating with acidified ethanol, this procedure was compared in four experiments using two rumen and two duodenal samples with a similar procedure in which ethanol alone replaced the ethanolic TCA. Results obtained by the former procedure were $97 \pm 2 \%$ for RNA and $99 \pm 3 \%$ for DNA of those obtained with ethanol alone. Since there was no appreciable difference between the two procedures ethanolic TCA was used routinely. In the remainder of the extraction procedure (steps 2-6) the recommendations of Hutchison \& Munro (1961) were followed closely except that sodium acetate was added to the ethanol wash (step 3) as recommended by Steele, Okamura \& Busch (1964) to buffer residual traces of acid. Care was taken that operations were carried out below $4^{\circ}$, at least until after the sodium acetate-ethanol wash. In practice, after

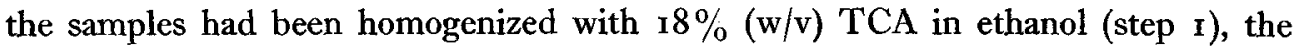
mixture was usually stored below $4^{\circ}$ overnight before continuing with steps $2-7$ on the following day. Comparative experiments showed that this delay did not affect the subsequent stability of DNA to alkaline hydrolysis (p. 675) and did not, in fact, affect the DNA results. For duodenal samples values with overnight storage were $98 \pm 2 \%$ (three samples) of samples treated immediately. The ether-dried residue was ground in an Alston Amalgamator (Dental Manufacturing Company, London) and stored at $4^{\circ}$. 
Alkaline digestion of the residue. In the procedure of Schmidt \& Thannhauser (I945) an acid-extracted fat-free residue is digested with $\mathrm{KOH}$ to hydrolyse RNA to acidsoluble nucleotides. The effect on the subsequent determination of RNA of varying the conditions of alkaline digestion for our samples is shown in Table I. Treatment with $0.3 \mathrm{~N}-\mathrm{KOH}$ for $\mathrm{I} \mathrm{h}$, recommended by Munro \& Fleck ( 1967 ) for animal tissue, was inadequate, at least for rumen and ileal samples. Treatment with $\mathrm{N}-\mathrm{KOH}$ for $20 \mathrm{~h}$ gave much better recoveries from these digesta samples and did not affect results for pure or crude yeast RNA. The main reported disadvantage of the more rigorous treatment is that additional materials, interfering in RNA determination, are made soluble in acid, but with our samples such materials elevated values by a factor of about 2-3 (cf. Fig. 3) irrespective of conditions. We therefore adopted the procedure shown in Fig. I (step 8).

\section{Determination of $D N A$ in alkaline digests and in perchloric acid extracts of ether-dried residue}

The soluble part of the alkaline digest (step 8) was neutralized with $4 \mathrm{~N}$-perchloric acid and excess acid was added to make the solution about $0.3 \mathrm{~N}$ (Hallinan et al. I $_{963}$ ) with respect to perchloric acid (step 9). During this treatment the mixture and reagents added were kept below $4^{\circ}$. After 30 min the mixture was separated into residue and supernatant fraction by centrifuging; the former was extracted with hot perchloric acid (step Io) and the latter was neutralized with $\mathrm{KOH}$ and filtered (step Ir). The solutions from both these steps were used for DNA determination.

Several methods based on estimations of deoxyribose were investigated. The method of Ceriotti (1952), in which DNA reacts with indole in acid solution and the coloured reaction product is extracted with chloroform, often gave higher values than the diphenylamine method of Burton (1956). It was found that with the high acid concentrations ( $12 \mathrm{~N}$ ) used by Ceriotti both xylose and arabinose, which are widely distributed in plant polysaccharides and almost certainly present in rumen digesta, interfered seriously with the determination. Keck (1956) has also reported interference by xylose. The effect of varying the acid concentration in the reaction is shown in Fig. 2. It was apparent that with very low acid concentrations the reaction with DNA was greatly inhibited, but that with final concentrations of $0.4-0.8 \mathrm{~N}$ interference was largely eliminated without serious loss of sensitivity. The following modified indole procedure was therefore adopted. A $2 \mathrm{ml}$ sample was neutralized with $\mathrm{NaOH}$ with methyl red as indicator. To this were added $\mathrm{I} \mathrm{ml} 3 \mathrm{~N}$-hydrochloric acid and I $\mathrm{ml}$ $0.05 \%(\mathrm{w} / \mathrm{v})$ indole in $10 \%$ aqueous ethanol and the volume was adjusted to $5 \mathrm{ml}$ with water. The mixture was heated at $100^{\circ}$ for $20 \mathrm{~min}$, cooled, the volume readjusted to $5 \mathrm{ml}$ and the mixture extracted with three successive $4 \mathrm{ml}$ volumes of chloroform. The yellow aqueous solution was clarified by centrifuging and absorption in the supernatant fraction measured at $490 \mathrm{~nm}$.

Results obtained by this method were $92 \pm 3 \%$ (eight experiments) of results obtained by the diphenylamine method of Burton (1956). Since the diphenylamine procedure was somewhat more sensitive and convenient to carry out it was adopted for most of our work. Results were expressed in terms of a sample of highly polymerized 
thymus DNA containing $\mathrm{I}_{4} .8 \%$ nitrogen (British Drug Houses Ltd), which was used as a final reference standard. A working standard prepared from a more crude thymus DNA sample (Koch-Light Laboratories Ltd) subjected to perchloric acid extraction (Fig. I, step I4) was used daily. This solution was stable for at least 2 months.

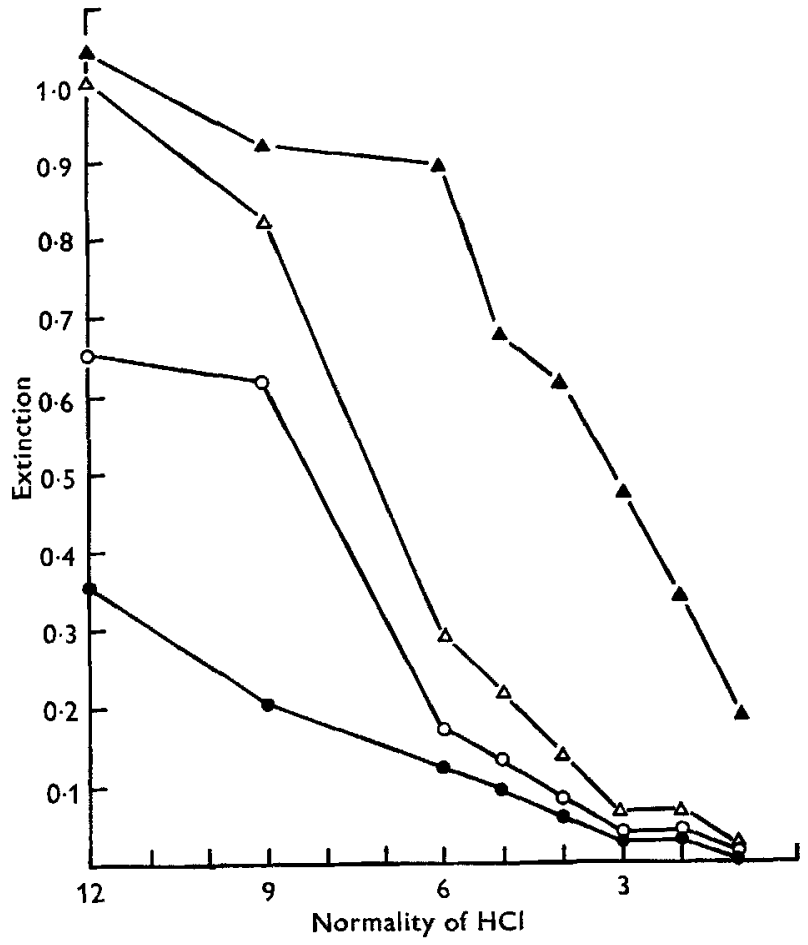

Fig. 2. Effect of varying the concentration of $\mathrm{HCl}$ on the interference caused by arabinose and xylose in the estimation of DNA by the indole procedure. $2 \mathrm{ml} \mathrm{sample}+\mathrm{I} \mathrm{ml} 0.04 \%$ aqueous indole were heated at $100^{\circ}$ for $10 \mathrm{~min}$ with $\mathrm{I} \mathrm{ml} \mathrm{HCl}$ of different concentrations. The mixture was cooled and extracted with three $\times 4 \mathrm{ml}$ volumes of chloroform. The aqueous layer was centrifuged and the absorption of the supernatant fraction at $490 \mathrm{~nm}$ measured. Sample solutions were $75 \mu \mathrm{g} / \mathrm{ml}$ DNA (A), I $\mathrm{mg} / \mathrm{ml} \mathrm{L-arabinose} \mathrm{(O),} \mathrm{I} \mathrm{mg} / \mathrm{ml} \mathrm{D-xylose} \mathrm{( \odot )} \mathrm{and}$ I $\mathrm{mg} / \mathrm{ml} \mathrm{L}$-arabinose + I $\mathrm{mg} / \mathrm{ml} \mathrm{D}$-xylose $(\triangle)$.

The values in Table 2 show that an appreciable amount of material reacting like deoxyribose (presumably DNA) was present in the acid-soluble fraction after alkaline digestion. This was contrary to most reported experience with animal tissue but was found consistently. In nine experiments $24 \pm 4 \%$ of the DNA was acid-soluble at this stage despite all precautions to avoid temperatures greater than $4^{\circ}$ when treatment conditions were acid. Neither carrying out the whole extraction procedure (to step 7) immediately after sample collection (instead of our usual practice of storing the initial homogenate overnight) nor the addition of egg albumin (Schmidt, Hecht \& Thannhauser, $1947-8$ ) or $\mathrm{MgCl}_{2}$ (Smillie \& Krotkov, I960) before precipitation reduced the amounts of acid-soluble DNA.

In an attempt to simplify the procedure the possibility of directly extracting the 


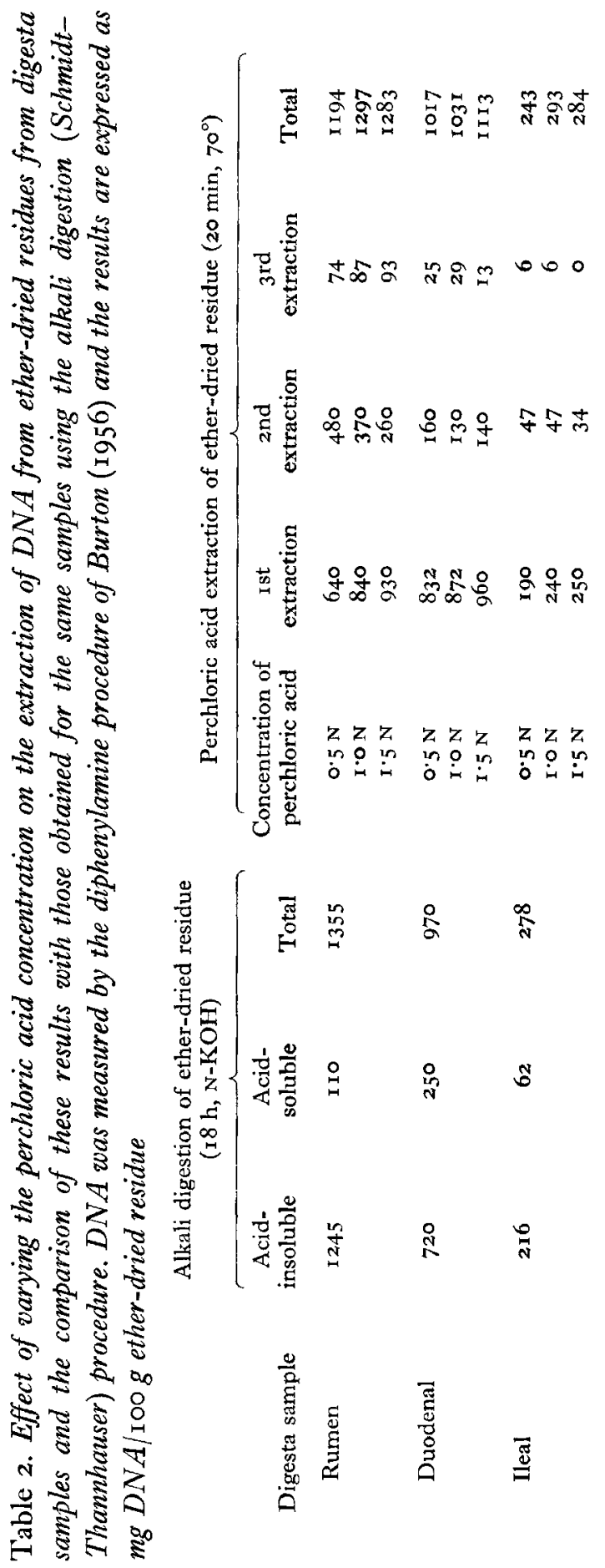


ether-dried residue with perchloric acid was investigated. The results of Hutchison, Downie \& Munro (I962) and Løvtrup \& Roos (I961) showed that temperatures above $70^{\circ}$ for this extraction were likely to lead to serious destruction of DNA. For the extraction of liver DNA at $70^{\circ}$, Hutchison et al. (1962) obtained the best results with $\mathrm{I} \cdot \mathrm{O}-2 \cdot 0 \mathrm{~N}$-perchloric acid although values were slightly lower than those obtained by the Schmidt-Thannhauser extraction procedure. For single $20 \mathrm{~min}$ extractions at $70^{\circ}$ of ether-dried residues from digesta we found that values for DNA in the extracts increased with increasing strength of perchloric acid used up to the maximum concentration of $\mathrm{r} \cdot 5 \mathrm{~N}$, but that with three successive extractions there was little difference between $\mathrm{I} \cdot \mathrm{O}$ and $\mathrm{I} \cdot 5 \mathrm{~N}$-perchloric acid (Table 2). When extracts were made in this way the total DNA obtained was similar to that obtained for total DNA (acidinsoluble + acid-soluble) by the Schmidt-Thannhauser procedure (Table 2). For routine estimation therefore we adopted the procedure shown as step I4 (Fig. I).

\section{Determination of RNA in alkaline digests of ether-dried residues}

An attempt was made to measure RNA in the acid-soluble part of the alkaline digest (step 9) by the orcinol method for ribose determination (Kerr \& Seraidarian, I 945 ) and by u.v. absorption at $260 \mathrm{~nm}$. Both methods gave extremely high values which did not correspond and the solutions gave u.v. absorption spectra which were quite dissimilar to those given by nucleotide solutions (Fig. 3). It appeared that considerable amounts of interfering materials were present. As stated earlier, the extent of this interference was not materially reduced by using milder alkaline hydrolysis in step 8. Although interference such as this does not appear to be a serious problem in most animal tissue investigations, some inteference has been reported in extracts from bacteria (de Deken-Grenson \& de Deken, 1959) and plant tissues (Smillie \& Krotkov, I96o; Holdgate \& Goodwin, 1965). The latter groups of workers removed the interfering substances found in alkaline hydrolysates from Chlorella and from rye seedlings respectively by passing the solution through a column of Dowex-I ion exchange resin and eluting the nucleotides with an $\mathrm{HCl}-\mathrm{NaCl}$ solution. We have investigated a similar technique for our samples. The acid-soluble part of the alkaline digest was neutralized with $\mathrm{KOH}$ (step II) and the filtrate buffered with $0.025 \mathrm{M}$-tris (tris(hydroxymethyl)aminomethane) at $\mathrm{pH} 7.8$ (step I2). About $30 \mathrm{ml}$ of this solution, containing up to $6 \mathrm{mg}$ total nucleotides (preliminary experiments showed that greater amounts of nucleotides were not retained quantitatively on the columns used), were added to a column $(15 \mathrm{~cm} \times 0.5 \mathrm{~cm})$ of Dowex-I $\times 10,50-100$ mesh ion exchange resin in the chloride form, the column was washed with $0.025 \mathrm{M}$-tris buffer and then eluted with $0.5 \mathrm{~N}-\mathrm{HCl}$ (step ${ }_{3}$ ). Inferior results were obtained on eluting with stronger or weaker $\mathrm{HCl}$ solutions and a solution of $\mathrm{N}-\mathrm{HCl}$ saturated with sodium chloride gave only half the recovery obtained with $\mathrm{N}-\mathrm{HCl}$ alone. Patterns of emergence of u.v. $(260 \mathrm{~nm})$ absorbing material from the column are shown in Fig. 4. For solutions prepared by alkaline hydrolysis of highly polymerized yeast RNA the u.v. $(260 \mathrm{~nm})$ absorbing material was present virtually entirely in the first $100 \mathrm{ml}$ of the eluate. Lower-grade laboratory yeast RNA (Koch-Light Laboratories Ltd) gave solutions for which about $3 \%$ of the u.v. absorbing material appeared in the tris washings (probably nucleosides 
-unpublished evidence) but virtually all the remainder in the $100 \mathrm{ml}$ eluate. For solutions prepared from digesta samples considerable amounts of material which absorbed u.v. $(260 \mathrm{~nm})$ and reacted with orcinol appeared in the early washings with tris buffer. The u.v. absorption spectra of these washings were however dissimilar from nucleic acids or their breakdown products. Fractions obtained by elution with

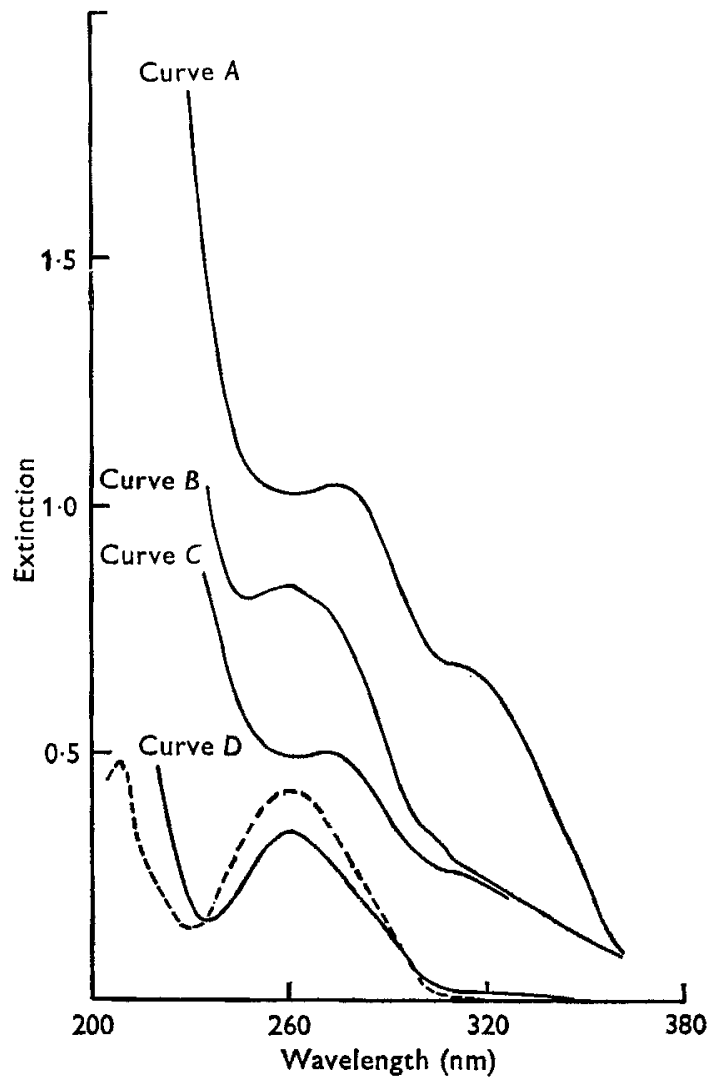

Fig. 3. Ultraviolet absorption spectra at different stages in the estimation of RNA from digesta samples. Curve $A$ is the spectrum of the acid-soluble fraction obtained at step 9 (Fig. I) after alkaline hydrolysis. Curve $C$ is the spectrum obtained for the buffered fraction after passing through the column combined with the buffered wash (step 13, Fig. I). This contains the interfering material which is not retained on the column. Curve $D$ is the spectrum of the solution of eluted nucleotides and is compared with the spectrum of a solution of pure highly polymerized yeast RNA (broken-line curve). Curve $B$ is a composite curve made up of curves $C$ and $D$, the difference between curve $A$ and $B$ shows the proportion of interfering material retained on the ion-exchange resin.

$0.5 \mathrm{~N}-\mathrm{HCl}$, at least from rumen and duodenal samples, had absorption spectra typical of nucleotides (Fig. 3). Spectra for fractions from ileal contents showed some distortion and it is possible that values estimated for these samples were slightly elevated. There was, however, even for ileal samples, good agreement between estimations based on u.v. $(260 \mathrm{~nm})$ absorption and the orcinol reaction. When the elution with $0.5 \mathrm{~N}-\mathrm{HCl}$ was continued beyond $100 \mathrm{ml}$ for the yeast RNA samples little or no further 
u.v. (260 nm) absorbing material was obtained. With digesta samples there was slight 'tailing' and further fractions continued to show some u.v. (260 $\mathrm{nm}$ ) absorption. This however was very small (less than $\mathrm{I} \%$ of the total in the next $100 \mathrm{ml}$ ) and u.v. absorption spectra were not typical of nucleotides. In all experiments with digesta samples there was some decrease in u.v. $(260 \mathrm{~nm})$ absorption between material added to the
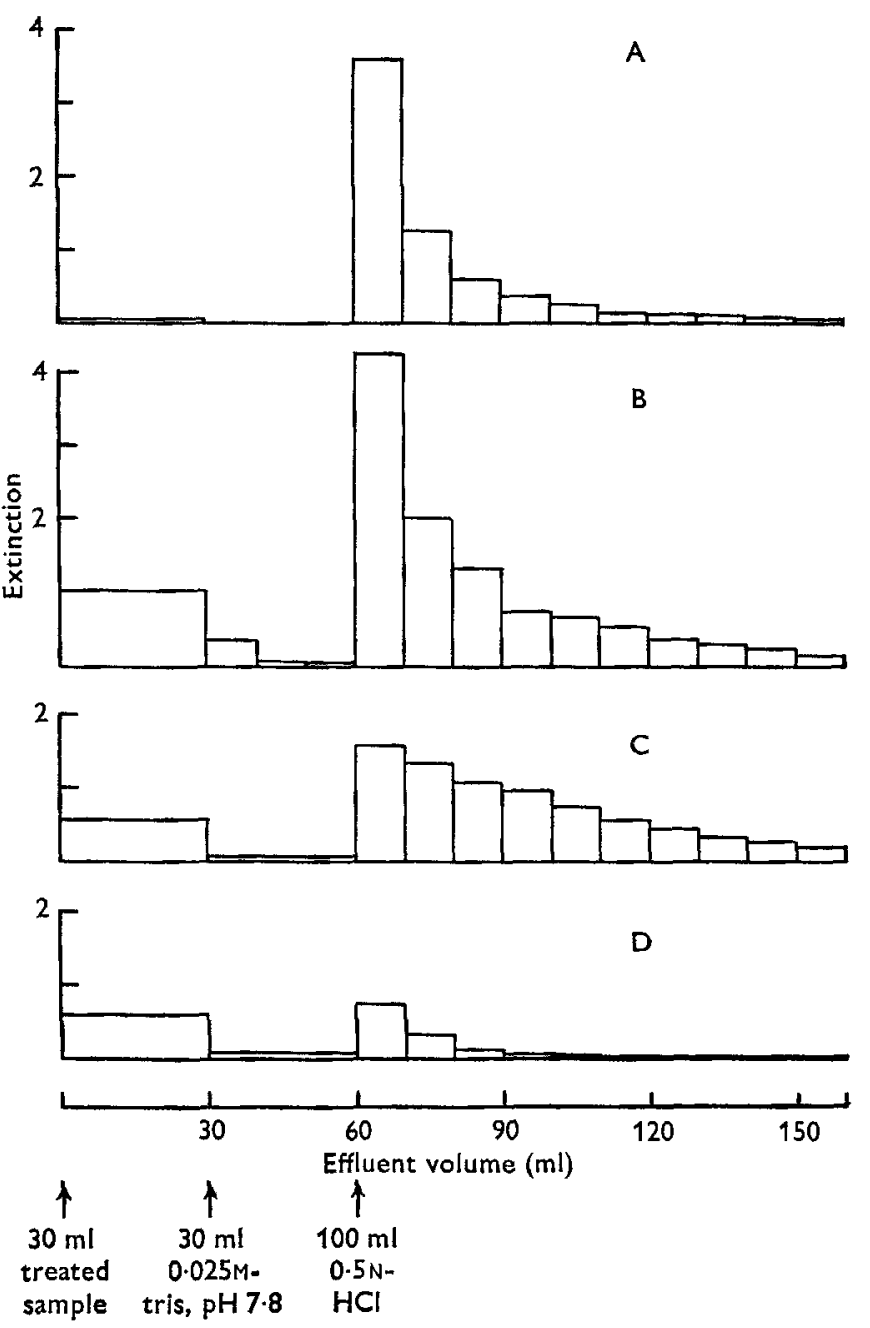

Fig. 4. Extinction at $260 \mathrm{~nm}$ of fractions of effluent from Dowex anion exchange columns following the procedure shown in Fig. I (step 13). The samples added to the column were prepared from pure yeast RNA (A), ruminal digesta (B), duodenal digesta $(C)$ and ileal digesta (D). Recovery of pure RNA in the acid eluate was $97 \%$.

column and the total recovered in the washings and eluate (cf. Fig. 3). It appeared that an appreciable amount of interfering material was retained on the column. There was, in fact, a coloured very slow-moving band the bulk of which remained near the top of the column and probably represented at least part of this material. This contaminating material was held very tenaciously and was not removed even after several 
hours washing with $0.5 \mathrm{~N}-\mathrm{HCl}$. Consequently resin was used only once and then discarded. When a resin with a lower degree of cross linking was tried (Dowex-I $\times 2$ ) much less interfering material was removed in the tris washings and more was retained on the column. This material, although more strongly held than the nucleotides, was not cleanly separated from them. Thus the slight 'tailing' observed with the highly cross-linked Dowex- $\mathrm{I} \times$ 10 was much greater with Dowex-I $\times 2$, and with the latter resin the first $100 \mathrm{ml} \mathrm{0.5} \mathrm{N}$-hydrochloric acid eluate did not show an absorption spectrum typical of nucleotides. Thus the effectiveness of Dowex-r $\times$ ro for purifying the nucleotide solutions appeared to rest partly in its ion-exchange properties but partly also in a molecular sieving effect.

The procedure finally adopted for RNA determination was that indicated in Fig. I. Preliminary experiments showed a close correspondence between estimations based on the orcinol reaction and on u.v. $(260 \mathrm{~nm})$ absorption. Orcinol values were $97 \pm 3 \%$, $97 \pm 6 \%$ and $96 \pm 5 \%$ of those obtained by u.v. absorption for rumen, abomasal and ileal digesta samples respectively (two experiments in each case). Therefore for most work the more easily carried out u.v. method was used. Results were expressed in terms of pure, highly polymerized yeast RNA containing $14.0 \%$ nitrogen (British Drug Houses Ltd), which was subjected to steps 8, 9, I I, I2 and I3 as a final reference standard. This was used to calibrate a working standard which was prepared by digesting 7•5 $\mathrm{g}$ lower-grade laboratory yeast RNA (Koch-Light Laboratories Ltd) with I $5 \circ \mathrm{ml} \mathrm{N}-\mathrm{KOH}$, centrifuging and washing the residue with $10 \mathrm{ml} \mathrm{N}-\mathrm{KOH}$. The combined supernatant fractions were cooled and acidified with $64 \mathrm{ml}$ cold $4 \mathrm{~N}$-perchloric acid, centrifuged and made up to a final volume of $250 \mathrm{ml}$. This solution, stored below $4^{\circ}$, was stable for at least 2 months and suitable samples were subjected to steps II, I2 and 13 as required.

\section{Recovery of known amounts of RNA and DNA added to digesta samples}

Recovery experiments were carried out with eight rumen and two duodenal samples derived from three calves receiving a variety of diets. The samples contained 9-60 $\mathrm{mg}$ DNA and 17-110 mg RNA per I00 g water. RNA (yeast) and DNA (thymus or herring sperm) were added to these samples in concentrations of $25^{-220} \mathrm{mg} / 100 \mathrm{~g}$ water and the mixtures were put through the standard procedure. Mean percentage recoveries for the nucleic acids added to the ten samples were $93 \pm 3 \%$ for RNA and $96 \pm 3 \%$ for DNA.

\section{DISCUSSION}

It is evident from the literature that no single method for nucleic acid extraction and estimation can be applied generally, and that conditions must be investigated thoroughly for individual materials. Any method chosen must, to some degree, be a compromise between practical considerations and the greatest accuracy. The procedure for digesta described in Fig. I has proved to be quite suitable for routine use and appeared to give good accuracy. It is difficult to establish with complete certainty the accuracy of a method applied to nucleic acids of unknown composition and in samples which cannot be obtained free of nucleic acids for checking purposes. However, a 
number of facts support the view that the method was satisfactory. (a) Overall recoveries of added nucleic acids were good. $(b)$ Determinations of DNA by the 'Schmidt-Thannhauser' technique (step Io plus a correction for acid-soluble DNA) agreed well with those by the 'Schneider' technique (step I4). (c) Determinations of DNA by the diphenylamine method of Burton (1956) and the modified indole method were in good agreement. Since the two reactions depend upon different mechanisms and show different specificity (Dische, 1955) this provided evidence that each was satisfactory. (d) Determinations of RNA by u.v. absorption at $260 \mathrm{~nm}$ and the orcinol reaction (Kerr \& Seraidarian, 1945) were also in good agreement.

This last fact suggests that there is little difference in u.v. absorption:orcinolcolour ratio between digesta RNA and yeast RNA but there is no other information on their relative properties. Estimates of total weight or nitrogen content of RNA present in a digesta sample were always made by reference to yeast RNA. The possible error involved in ignoring differences between different nucleic acids should be borne in mind although it is probably small and of little consequence in comparative investigations. Analogous considerations apply to results for DNA which were expressed in terms of thymus DNA.

According to Hutchison \& Munro (I96r), a finding that considerable proportions of DNA are rendered soluble in acid after alkaline hydrolysis usually indicates that samples have been subjected to acid conditions at temperatures above about $4^{\circ}$ during treatment. This leads to degradation of DNA to apurinic acid. We carefully avoided such conditions but still found that about $24 \%$ of the DNA (as indicated by deoxyribose determination) was acid-soluble in step 9. Ingle ( 1963$)$, working with various plant tissues, also found that $20-25 \%$ of the DNA was acid-soluble after similar treatment.

The presence of DNA in the acid-soluble fraction used in step II suggests that it might interfere in the determination of RNA. However, no deoxyribose was detected in the nucleotide fraction from the Dowex column (step I3) and the addition of DNA to digesta samples in amounts three times greater than those found in the samples had no effect on RNA determination. Addition of amounts five times greater than in the samples caused only a small increase (about $6 \%$ ) in RNA determination. It appears that the soluble DNA was, in fact, retained on the column. Volkin \& Astrachan (1956) found that the removal of bacterial DNA from a similar resin could be achieved only by boiling with $5 \mathrm{~N}-\mathrm{HCl}$.

\section{REFERENCES}

Burton, K. (1956). Biochem. F. 62, 315.

Ceriotti, G. (1952). F. biol. Chem. r98, 297.

de Deken-Grenson, M. \& de Deken, R. H. (1959). Biochim. biophys. Acta 31, 195.

Dische, Z. (1955). In The Nucleic Acids, p. 285. [E. Chargaff \& J. N. Davidson, editors.] New York: Academic Press Inc.

Ellis, W. C. \& Pfander, W. H. (1965). Nature, Lond. 205, 974.

Gausseres, B. \& Fauconneau, G. (1965). Annls Biol. anim. Biochim. Biophys. 5, 5.

Hallinan, T., Fleck, A. \& Munro, H. N. (1963). Biochim. biophys. Acta 68, I3 I.

Holdgate, D. P. \& Goodwin, T. W. (1965). Phytochemistry 4, 83 I.

Hutchison, W. C., Downie, E. D. \& Munro, H. N. (1962). Biochim. biophys. Acta 55, 56r.

Hutchison, W. C. \& Munro, H. N. (1961). Analyst, Lond. 86, 768. 
Hutchison, W. C. \& Munro, H. N. (1962). Analyst, Lond. 87, $3{ }^{\circ} 3$.

Ingle, J, (1963). Phytochemistry 2, 353.

Keck, K. (1956). Archs Biochem. Biophys. 63, 446.

Kerr, S. E. \& Seraidarian, K. (1945). F. biol. Chem. 159, 2 r.

Løvtrop, S. \& Roos, K. (1961). Biochim. biophys. Acta 53, I.

McAllan, A. B. \& Smith, R. H. (1968). Proc. Nutr. Soc. 27, 47 A.

McDonald, I. W. (1954). Biochem. \%. 57, 566.

Munro, H. N. \& Fleck, A. (1966). Analyst, Lond. 91, 78.

Munro, H. N. \& Fleck, A. (1967). Meth. biochem. Analysis 14, 113.

Schmidt, G., Hecht, L. \& Thannhauser, S. J. (1947-8). J. gen. Physiol. 31, 203.

Schmidt, G. \& Thannhauser, S. J. (1945). F. biol. Chem. r6r, 83.

Schneider, W. C. (1945). F. biol. Chem. 161, 293 .

Smillie, R. M. \& Krotkov, G. (I960). Can. F. Bot. 38, $3^{\text {I. }}$

Smith, R. H., McAllan, A. B. \& Hill, W. B. (1968). Proc. Nutr. Soc. 27, 48A.

Steele, W. J., Okamura, N. \& Busch, H. (1964). Biochim. biophys. Acta 87, 490.

Topps, J. H. \& Elliott, R. C. (1965). Nature, Lond. 205, 498.

Volkin, E. \& Astrachan, L. (1956). Virology 2, 149 . 